\title{
Biomarkers in Nile Tilapia Oreochromis niloticus niloticus (Linnaeus, 1758) to Assess the Impacts of River Nile Pollution: Bioaccumulation, Biochemical and Tissues Biomarkers
}

\author{
Alaa G. M. Osman ${ }^{1,2}$ \\ ${ }^{1}$ Department of Zoology, Faculty of Science, Al-Azhar University (Assiut Branch), Assiut, Egypt; ${ }^{2}$ Department of Ecophysiology \\ and Aquaculture, Leibniz-Institute of Freshwater Ecology and Inland Fisheries, Berlin, Germany. \\ Email: osman@igb-berlin.de
}

Received June $7^{\text {th }}, 2012$; revised July $6^{\text {th }}, 2012$; accepted August $2^{\text {nd }}, 2012$

\begin{abstract}
The use of biomarkers has become an important tool for modern environmental assessment as they can help to predict pollutants involved in the monitoring program. Here I present data on bioaccumulation, biochemical and tissues biomarkers in Nile tilapia as early warning indicators of river Nile pollution. Nile tilapia sampled from downstream sites accumulated higher levels of all the detected heavy metals than those collected from upstream sites. Heavy metal residues in the tissues of Nile tilapia exhibited different patterns of accumulation and distribution among the selected tissues. Remarkable alterations in the activities of glucose-6-phosphate dehydrogenase (G6PDH) and lactate dehydrogenase (LDH) in the tissues of Nile tilapia were detected. These alterations were followed, in the present study, by the occurrence of histological lesions in liver and gill tissues of fish collected from the same sites. Alterations in bioaccumulation patterns, in enzyme activities and in histology go in parallel with the elevation in the levels of water chemical parameters detected in the downstream sites as a result of pollution stress in these areas. These results provide evidence that bioaccumulation, biochemical and tissues biomarkers can be sensitive indicators of exposure to mixed pollutants in surface waters.
\end{abstract}

Keywords: Biomarkers; Bioaccumulation; Enzyme Activities; Histopathology; Nile Tilapia; River Nile

\section{Introduction}

The river Nile can be considered as a model polluted aquatic ecosystem for assessment of biomarker responses in fish because it receives untreated wastes from various drain outlets $[1,2]$. The use of biomarkers has become an important tool for modern environmental assessment as they can help to predict pollutants involved in the monitoring program. Currently, the use of biomarkers for monitoring environmental quality has gained considerable interest in the assessment of river condition in many places around the world $[3,4]$. There are many different biomarkers that occur at many different levels of organization from sub-cellular to whole-organisms. The biomarker may be the chemical itself (bioaccumulation). It may also be molecular biomarkers, biochemical biomarkers and tissues biomarkers.

Metal bioaccumulation is a major route, through which increased levels of the pollutants are transferred across the food chain and finally assimilated by human con- sumers resulting in health risks [5]. Therefore, it is important to always determine the bioaccumulation capacity for heavy metals by fishes in order to assess potential risk to human health and take appropriate action to protect public health and the environment $[5,6]$. Contaminant residues in fish tissues may ultimately reach concentrations hundreds or thousands of times above those measured in the water [1]. For this reason, monitoring fish tissue contamination serves an important function as an early warning biomarker of aquatic pollution [7].

Monitoring changes in biochemical parameters may provide early warning indicators of general as well as specific toxicological responses. Biochemical biomarkers of contamination are important indices used in fish toxicity tests and for field monitoring of aquatic pollution [8]. In toxicological studies of acute exposure, changes in concentrations and activities of some enzymes may reflect cell damage in specific organs [9]. Glucose-6phosphate dehydrogenase (G6PDH) has long been recognized as an antioxidant enzyme [10] and also as a 
biomarker of pollution-induced carcinogenesis in fish. The cytoplasmic enzyme lactate dehydrogenase (LDH) is widely used as marker of organ or tissue lesions in toxicology and in clinical chemistry [11,12]. G6PDH and LDH are key factors in the metabolism with high sensitivity to pollutants [13].

Tissue biomarkers are closely related to other biomarkers of stress since many pollutants have to undergo metabolic activation in order to be able to provoke tissues change in the exposed organism. The advantage of histopathology as an excellent biomarker lies in its intermediate location between molecular and individual levels [14-16]. Most biomarkers are narrow in their expression whereas pathology is broad in its evaluation [17].

Fish are widely used to evaluate the health of aquatic systems and their biological responses serve as biomarkers of environmental contaminants. Besides its ecological value, Nile tilapia, Oreochromis niloticus niloticus, also economically important as a food source by low income families along the river Nile. Nile tilapia is one of the most common freshwater fish used in toxicological studies [18-20], because it presents a number of characteristics that may make it an appropriate model that can be used as indicator species in biomonitoring programs $[18,21]$.

Although biomarker studies in relation to water bodies in many countries have been extensively documented, scientific reports of pollutant induced biomarker responses in the river Nile are meager $[1,2,22]$. In the river Nile, contaminants are present as very complex mixtures and there is no single biomarker that can give a complete diagnosis of environmental degradation. To overcome this difficulty, a battery of biomarkers comprising molecular, bioaccumulation, biochemical and tissues biomarkers in Nile tilapia were used to assess stressful environmental conditions on the river Nile as well as point out which biomarkers to use during future monitoring programs of this and similar aquatic systems. In earlier publication, the author presented the results of molecular biomarker measurements in Nile tilapia from the river Nile $[2,23]$. Therefore as a consequence, in this study I present an investigation of bioaccumulation, biochemical and tissue biomarkers in Nile tilapia collected from the whole course of the Egyptian river Nile.

\section{Materials and Methods}

\subsection{Sampling Sites}

Six sites were selected along the whole course of the Egyptian river Nile from its start at Aswan to its estuaries at Rosetta and Damietta (Figure 1). Water and tissues samples from the selected sites were sampled bimonthly

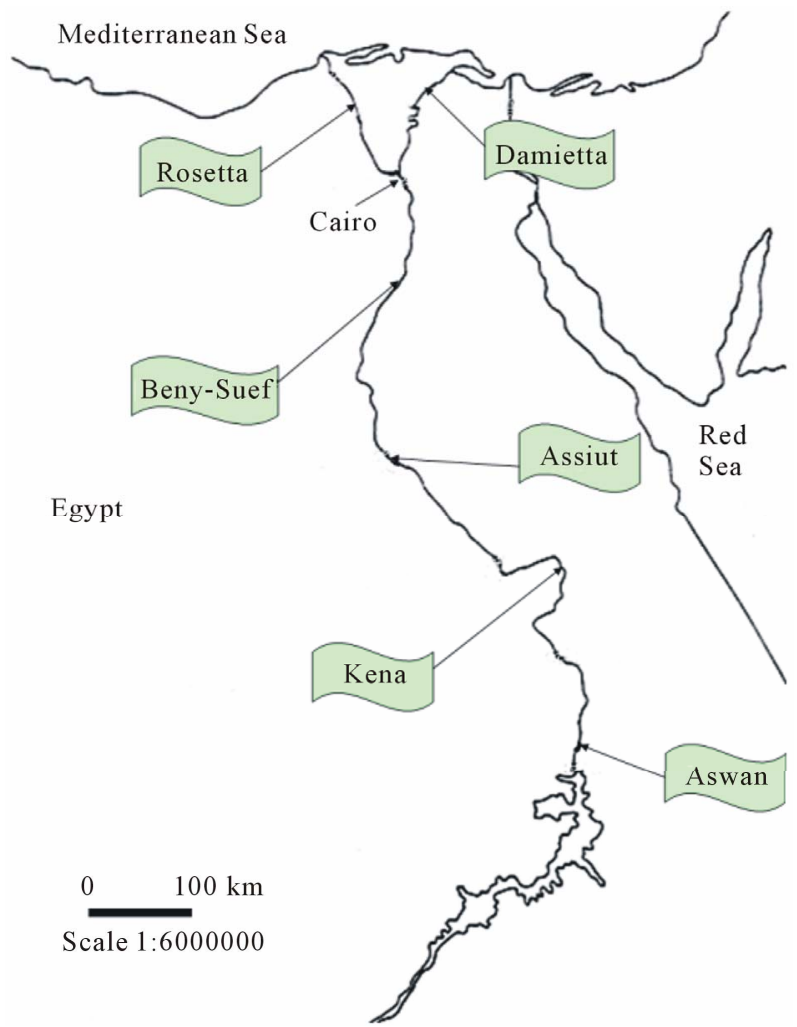

Figure 1. Map showing the sampling sites along the whole course of the Egyptian river Nile from its start at Aswan to its estuaries at Damietta and Rosetta sites.

(every two months) from the main course of the river Nile during the period from July 2009 to Jun 2010. Water samples (108 samples) were collected by polyvinyl chloride Van Dorn water sampler (5 L capacity) at two meter depths. Sampling and preservation of water samples were done according to the traditional manual methods [24]. Nile tilapia (Oreochromis niloticus niloticus) was caught by gill net from the selected sites ( 72 specimens; 12 fish from each sampling site). The body weight of the collected specimens ranged from $240-290 \mathrm{~g}$. The target organs (liver, gills, gonads and muscles) were excised for subsequent analysis.

\subsection{Water Quality Assessment}

Water quality criteria including the $\mathrm{pH}$, electrical conductivity $(\mathrm{mScm}-1)$ and temperature $\left({ }^{\circ} \mathrm{C}\right)$ were measured by using water checker U-10 Horiba Ltd. The other water criteria [chemical oxygen demand (COD), total organic carbon (TOC), total solids (TS), ammonia $\left(\mathrm{NH}_{3}\right)$, nitrate $\left(\mathrm{NO}_{3}\right)$, chloride $(\mathrm{CL})$ florid $(\mathrm{F})$, orthophosphate $\left(\mathrm{O}-\mathrm{PO}_{4}\right)$, sulphate $\left(\mathrm{SO}_{4}\right)$ and phenolics (Phenol)] were measured according to the traditional manual methods [24]. Total copper $(\mathrm{Cu})$, chromium $(\mathrm{Cr})$, cadmium $(\mathrm{Cd})$, zinc $(\mathrm{Zn})$, iron $(\mathrm{Fe})$, lead $(\mathrm{Pb})$, manganese $(\mathrm{Mn})$ and mercury $(\mathrm{Hg})$ 
were measured after digestion using Graphite Furnace AA (GFAA) spectroscopy. Data on the selected sites are shown in Table 1.

\subsection{Bioaccumulation Biomarker}

Liver, gills, gonads and muscles were transported in liquid nitrogen container to the laboratory for chemical analysis. They were washed with tap water (previously analyzed for $\mathrm{Pb}$ and $\mathrm{Cd}$ ) followed by bi-distilled water, then oven-dried to constant weight at $105^{\circ} \mathrm{C}$. The dried fish was crushed and powdered in an agate mortar, then, they were kept in polyethylene bottles for analysis. One gram portions of fish tissues were digested by means of a microwave after addition of nitric acid and hydrogen peroxide. The results were calculated in milligram per kilogram wet weight ( $\mathrm{mg} / \mathrm{kg}$ wet wt). Chemicals concen- tration were analyzed according to German industrial standard, DIN 38406-6, (DEV, E6) with an Atomic Absorption Spectrometer using flame and graphite furnace technique.

\subsection{Biochemical Biomarker}

The activities of Glucose-6-phosphate dehydrogenase (G6PDH) and lactate dehydrogenase (LDH) were measured according to a modified protocol based on $[25,26]$. Liver and muscles samples were pulverized under liquid nitrogen and about $100 \mathrm{mg}$ of ground tissue powder was

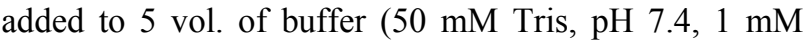
EDTA and $2 \mathrm{mM} \mathrm{MgCl}_{2}$ ). Tissue was homogenized briefly with an Ultra-Turrax (temperature was maintained at $4^{\circ} \mathrm{C}$ during homogenization). The homogenate was centrifuged for $15 \mathrm{~min}$ at $10,000 \times \mathrm{g}$ and $4^{\circ} \mathrm{C}$ and

Table 1. Physical and chemical parameters of water samples collected from different sites along the whole course of the river Nile, Egypt.

\begin{tabular}{|c|c|c|c|c|c|c|c|}
\hline Sites & Aswan & Kena & Assiut & Beny-Suef & Damietta & Rosetta & \multirow{2}{*}{$\underset{\text { limit }^{*}}{\text { Permissible }}$} \\
\hline Parameter (unit) & Mean \pm SD & Mean \pm SD & Mean \pm SD & Mean \pm SD & Mean \pm SD & Mean \pm SD & \\
\hline PH (Unit) & $7.86 \pm 0.25$ & $8.01 \pm 0.41$ & $8.15 \pm 0.18$ & $8.27 \pm 0.27$ & $8.40 \pm 0.44$ & $8.23 \pm 0.45$ & $7-8.5$ \\
\hline Conductivity ( Ms/cm) & $0.26 \pm 0.03$ & $0.27 \pm 0.07$ & $0.29 \pm 0.09$ & $0.34 \pm 0.07$ & $0.38 \pm 0.01$ & $0.58 \pm 0.12$ & - \\
\hline Temperature $\left({ }^{\circ} \mathrm{C}\right)$ & $22.68 \pm 2.22$ & $23.72 \pm 3.15$ & $23.33 \pm 4.67$ & $23.64 \pm 4.24$ & $25.29 \pm 5.66$ & $24.53 \pm 4.44$ & Over $5^{\circ} \mathrm{C}$ \\
\hline Chemical oxygen demand (ppm) & $10.58 \pm 3.62$ & $9.17 \pm 3.04$ & $10.63 \pm 2.18$ & $7.87 \pm 2.15$ & $8.59 \pm 2.51$ & $18.00 \pm 10.38$ & 10 \\
\hline Total organic carbon (ppm) & $5.65 \pm 2.88$ & $5.89 \pm 1.93$ & $5.74 \pm 0.92$ & $4.93 \pm 2.58$ & $5.21 \pm 2.63$ & $8.61 \pm 6.06$ & - \\
\hline Total solid (ppm) & $198.88 \pm 14.01$ & $212.67 \pm 23.7$ & $227.75 \pm 16.3$ & $259.5 \pm 44.33$ & $305.25 \pm 55.95$ & $411.25 \pm 85.66$ & 500 \\
\hline Ammonia (ppm) & $0.11 \pm 0.16$ & $0.009 \pm 0.001$ & $0.019 \pm 0.01$ & $0.01 \pm 0.009$ & $0.04 \pm 0.05$ & $0.15 \pm 0.09$ & 0.5 \\
\hline Nitrate (ppm) & $0.81 \pm 0.40$ & $0.76 \pm 0.39$ & $0.51 \pm 0.20$ & $0.72 \pm 0.63$ & $1.13 \pm 1.13$ & $2.05 \pm 2.27$ & 45 \\
\hline Chlorides (ppm) & $7.05 \pm 1.4$ & $8.56 \pm 1.89$ & $10.03 \pm 2.58$ & $15.28 \pm 5.10$ & $22.42 \pm 4.93$ & $40.55 \pm 6.72$ & - \\
\hline Florid (ppm) & $0.28 \pm 0.15$ & $0.32 \pm 0.13$ & $0.39 \pm 0.16$ & $0.31 \pm 0.13$ & $0.30 \pm 0.09$ & $0.37 \pm 0.07$ & 0.5 \\
\hline Ortho phosphate (ppm) & $0.01 \pm 0.02$ & $0.04 \pm 0.04$ & $0.09 \pm 0.09$ & $0.03 \pm 0.03$ & $0.13 \pm 0.07$ & $0.21 \pm 0.18$ & - \\
\hline Sulphate (ppm) & $34.17 \pm 13.30$ & $45.33 \pm 15.37$ & $47.96 \pm 14.11$ & $45.25 \pm 15.81$ & $51.00 \pm 12.76$ & $68.13 \pm 11.42$ & 200 \\
\hline Phenol (ppm) & $0.02 \pm 0.02$ & $0.02 \pm 0.02$ & $0.02 \pm 0.016$ & $0.02 \pm 0.009$ & $0.03 \pm 0.02$ & $0.04 \pm 0.02$ & 0.02 \\
\hline Cu (ppm) & $0.03 \pm 0.03$ & $0.03 \pm 0.024$ & $0.03 \pm 0.03$ & $0.03 \pm 0.03$ & $0.03 \pm 0.03$ & $0.05 \pm 0.03$ & 1 \\
\hline Cr (ppm) & $0.003 \pm 0.002$ & $0.007 \pm 0.01$ & $0.006 \pm 0.01$ & $0.006 \pm 0.01$ & $0.05 \pm 0.06$ & $0.09 \pm 0.15$ & 0.05 \\
\hline Cd (ppm) & $0.004 \pm 0.004$ & $0.002 \pm 0.002$ & $0.006 \pm 0.01$ & $0.002 \pm 0.002$ & $0.016 \pm 0.02$ & $0.01 \pm 0.02$ & 0.1 \\
\hline Zn (ppm) & $0.21 \pm 0.17$ & $0.12 \pm 0.10$ & $0.31 \pm 0.46$ & $0.34 \pm 0.45$ & $0.46 \pm 0.68$ & $0.7 \pm 0.96$ & 1 \\
\hline $\mathrm{Fe}(\mathrm{ppm})$ & $0.19 \pm 0.17$ & $0.22 \pm 0.19$ & $0.34 \pm 0.32$ & $0.46 \pm 0.39$ & $0.412 \pm 0.27$ & $0.5 \pm 0.44$ & 1 \\
\hline Pb (ppm) & $0.01 \pm 0.02$ & $0.02 \pm 0.01$ & $0.02 \pm 0.01$ & $0.02 \pm 0.01$ & $0.03 \pm 0.04$ & $0.06 \pm 0.078$ & 0.05 \\
\hline Mn (ppm) & $0.03 \pm 0.03$ & $0.06 \pm 0.06$ & $0.05 \pm 0.02$ & $0.06 \pm 0.06$ & $0.07 \pm 0.08$ & $0.1 \pm 0.15$ & 0.5 \\
\hline Hg (ppm) & $0.0009 \pm 0.001$ & $0.0004 \pm 0.001$ & $0.0005 \pm 0.001$ & $0.0009 \pm 0.001$ & $0.002 \pm 0.001$ & $0.003 \pm 0.001$ & 0.001 \\
\hline
\end{tabular}

${ }^{*}$ Canadian environmental quality guidelines. 
supernatants were used for the enzyme activity assays using spectrophotometer (Micro Lab 200 Vital Scientific, Dieren, The Netherlands) at a wavelength of $340 \mathrm{~nm}$ and at $37^{\circ} \mathrm{C}$ using kits, Stanbio LDH (UV-Rate) procedure no. 0940 USA for the quantitative determination of LDH and RANDOX Laboratories Ltd., PD410, UK BT294QY, for the quantitative determination of G6PDH. The catalytic activities of the selected enzymes were calculated in accordance with the recommendations of the French Society of Clinical Biology and were expressed as U/g tissues [22].

\subsection{Tissue Biomarker}

Nile tilapias sampled from the selected sites were sacrificed by decapitation. Liver and gill were dissected out, fixed in Bouin's solution and then processed by conventional method [27], sectioned at $4-7 \mu \mathrm{m}$ and stained with Haematoxylin-eosine. The sections were observed under light microscopy. The histological changes in the liver and gill were examined [14] in the randomly selected sections from each fish and photographed using Leica Wild MPS48 microscope and CCD video camera (Sony, AVT-Horn).

\subsection{Statistical Analysis}

All values from chemical analyses and enzyme activities are presented as mean $\pm \mathrm{SD}$. Data obtained from the experiment were subjected to one way analysis of variance (ANOVA) test using the Statistical Package for the Social Sciences [28]. The correlation coefficients between heavy metals of water and tissues samples were calculated by the application of Pearson correlation analysis [29] in order to indicate the nature and the sources of the polluting substances. In all cases, $\mathrm{p}<0.05$ was the accepted significance level [28].

\section{Results}

\subsection{Water Analysis}

The results of means and SD of the detected physical and chemical parameters for water samples are given in Table 1. Most of the detected physicochemical parameters exhibited their highest values in the water of river Nile downstream. For nearly all the detected parameters significant differences $(p<0.05)$ were observed between the selected sites. According to the present results the $\mathrm{pH}$ seems to be constant all over the river Nile. All the $\mathrm{pH}$ values were in the alkaline side (7.8 to 8.4). Mean values of conductivity, COD, TOC, $\mathrm{NH}_{3}, \mathrm{NO}_{3}, \mathrm{TS}, \mathrm{SO}_{4}, \mathrm{Cl}$, orthophosphate and phenolics were higher in the water of Damietta and Rosetta sites compared to other sites. The value of $\mathrm{COD}$ and the concentrations of phenolics, lead, chromium, cadmium and mercury were higher than the permissible limits in Rosetta and/or Damietta sites (Table 1).

\subsection{Bioaccumulation Biomarker}

The mean concentrations of the selected heavy metals in liver, gill, gonad and muscle samples of Nile tilapia are presented in Table 2. Detected heavy metals concentrations varied widely between different sites and tissues. The highest concentrations of all the heavy metals were recorded in tissues samples collected from downstream river Nile (Damietta and/or Rosetta) and the lowest ones were detected in the samples collected from upstream areas (Aswan and/or Kena; Table 2). For nearly all the detected heavy metals significant differences $(\mathrm{p}<0.05)$ were recorded between the selected sites. Liver concentrated higher levels of $\mathrm{Cu}, \mathrm{Cr}, \mathrm{Cd}, \mathrm{Zn}, \mathrm{Fe}$ and $\mathrm{Pb}$ than the other organs for all the six sites (Table 2).

The distributions of all these heavy metals were in the order of liver $>$ gill $>$ gonad $>$ muscle. The highest concentration of Mn was recorded in the gills of fishes collected from nearly all the sites (Table 2). The distribution of Mn was in the order of gill $>$ liver $>$ gonad $>$ muscle nearly in all the sites (excluded Aswan and Damietta). The mean concentration of $\mathrm{Hg}$ was very low in all the tissues. According to the present result the $\mathrm{Hg}$ accumulated mainly in the liver followed by gills of fishes collected from all the sites except Kena and Assiut. In the latter two sites, the highest $\mathrm{Hg}$ concentrations were recorded in the gill tissues. Gonad and muscle were found to accumulate small amounts of all the detected heavy metals. Significant $(\mathrm{p}<0.05)$ high correlations (from 0.951 to 0.988 ) were observed between the concentrations of the selected heavy metals in the water and tissues of Nile tilapia.

\subsection{Biochemical Biomarkers}

The activities of the selected two metabolic enzymes (G6PDH and LDH) in the liver and muscles of Nile tilapia collected from the whole course of the Egyptian river Nile are presented in Table 3.

For both enzymes significant differences $(p<0.05)$ were detected between the selected sites. The activity of G6PDH in the liver and muscles of Nile tilapia decreased significantly $(\mathrm{p}<0.05)$ from Aswan toward Damietta and Rosetta sites (Table 3). The highest G6PDH activity was recorded in the liver $(57.7 \mathrm{U} / \mathrm{g})$ and muscles $(61.8 \mathrm{U} / \mathrm{g})$ of fish collected from Aswan (Table 3). On the other hand the lowest G6PDH activity was recorded in the liver and muscle tissues collected from Rosetta (Table 3). The activity of LDH in the muscles and liver of Nile tilapia increased significantly $(p<0.05)$ from upstream 
Table 2. Heavy metals concentrations in different tissues of Nile tilapia Oreochromis niloticus niloticus collected from different sites along the whole course of the river Nile, Egypt.

\begin{tabular}{|c|c|c|c|c|c|c|c|}
\hline Parameters & Organs & $\begin{array}{c}\text { Aswan } \\
\text { Mean } \pm \text { SD }\end{array}$ & $\begin{array}{c}\text { Kena } \\
\text { Mean } \pm \mathrm{SD}\end{array}$ & $\begin{array}{c}\text { Assiut } \\
\text { Mean } \pm \text { SD }\end{array}$ & $\begin{array}{l}\text { Beny-Suef } \\
\text { Mean } \pm \text { SD }\end{array}$ & $\begin{array}{c}\text { Damietta } \\
\text { Mean } \pm \mathrm{SD}\end{array}$ & $\begin{array}{c}\text { Rosetta } \\
\text { Mean } \pm \text { SD }\end{array}$ \\
\hline \multirow{4}{*}{$\mathrm{Cu}$} & Liver (L) & $16.39 \pm 3.66$ & $35.83 \pm 7.06$ & $25.75 \pm 17.44$ & $20.04 \pm 9.07$ & $34.30 \pm 26.59$ & $23.53 \pm 4.56$ \\
\hline & Gills (GL) & $3.13 \pm 0.91$ & $4.38 \pm 4.01$ & $17.51 \pm 2.94$ & $8.59 \pm 7.88$ & $23.96 \pm 10.28$ & $12.54 \pm 1.01$ \\
\hline & Gonads (G) & $2.45 \pm 3.06$ & $3.29 \pm 1.84$ & $12.2 \pm 6.59$ & $5.08 \pm 6.39$ & $5.58 \pm 2.21$ & $27.27 \pm 22.44$ \\
\hline & Muscles (M) & $0.796 \pm 0.67$ & $0.47 \pm 0.32$ & $4.53 \pm 2.71$ & $2.43 \pm 1.86$ & $5.75 \pm 4.43$ & $10.69 \pm 4.59$ \\
\hline \multirow[t]{2}{*}{ Pattern } & & $\mathrm{L}>\mathrm{GL}>\mathrm{G}>\mathrm{M}$ & $\mathrm{L}>\mathrm{GL}>\mathrm{G}>\mathrm{M}$ & $\mathrm{L}>\mathrm{GL}>\mathrm{G}>\mathrm{M}$ & $\mathrm{L}>\mathrm{GL}>\mathrm{G}>\mathrm{M}$ & $\mathrm{L}>\mathrm{GL}>\mathrm{G}>\mathrm{M}$ & $\mathrm{L}>\mathrm{G}>\mathrm{GL}>\mathrm{M}$ \\
\hline & Liver (L) & $6.26 \pm 1.98$ & $6.63 \pm 2.42$ & $6.39 \pm 1.63$ & $6.27 \pm 3.14$ & $10.56 \pm 2.83$ & $13.74 \pm 3.82$ \\
\hline \multirow{3}{*}{$\mathrm{Cr}$} & Gills (GL) & $5.74 \pm 3.29$ & $6.59 \pm 1.28$ & $5.13 \pm 1.96$ & $5.69 \pm 3.34$ & $6.05 \pm 4.63$ & $13.11 \pm 2.02$ \\
\hline & Gonads (G) & $5.19 \pm 1.35$ & $5.52 \pm 2.03$ & $4.78 \pm 1.07$ & $4.53 \pm 2.14$ & $4.01 \pm 3.67$ & $11.65 \pm 1.16$ \\
\hline & Muscles (M) & $3.93 \pm 2.43$ & $4.78 \pm 1.79$ & $3.71 \pm 1.23$ & $4.45 \pm 2.1$ & $2.64 \pm 1.76$ & $7.87 \pm 7.67$ \\
\hline \multirow[t]{2}{*}{ Pattern } & & $\mathrm{L}>\mathrm{GL}>\mathrm{G}>\mathrm{M}$ & $\mathrm{L}>\mathrm{GL}>\mathrm{G}>\mathrm{M}$ & $\mathrm{L}>\mathrm{GL}>\mathrm{G}>\mathrm{M}$ & $\mathrm{L}>\mathrm{GL}>\mathrm{G}>\mathrm{M}$ & $\mathrm{L}>\mathrm{GL}>\mathrm{G}>\mathrm{M}$ & $\mathrm{L}>\mathrm{GL}>\mathrm{G}>\mathrm{M}$ \\
\hline & Liver (L) & $0.94 \pm 0.25$ & $1.19 \pm 0.63$ & $1.03 \pm 0.21$ & $1.11 \pm 0.57$ & $3.32 \pm 1.32$ & $1.7 \pm 1.17$ \\
\hline \multirow{3}{*}{$\mathrm{Cd}$} & Gills (GL) & $0.80 \pm 0.39$ & $0.75 \pm 0.48$ & $0.94 \pm 0.13$ & $1.05 \pm 0.41$ & $1.68 \pm 0.67$ & $1.18 \pm 0.59$ \\
\hline & Gonads (G) & $0.79 \pm 0.47$ & $0.62 \pm 0.17$ & $0.92 \pm 0.37$ & $0.98 \pm 0.45$ & $1.52 \pm 0.47$ & $1.07 \pm 0.62$ \\
\hline & Muscles (M) & $0.67 \pm 0.64$ & $0.58 \pm 0.29$ & $0.89 \pm 0.34$ & $0.71 \pm 0.25$ & $0.89 \pm 0.43$ & $1.02 \pm 0.42$ \\
\hline \multirow[t]{2}{*}{ Pattern } & & $\mathrm{L}>\mathrm{GL}>\mathrm{G}>\mathrm{M}$ & $\mathrm{L}>\mathrm{GL}>\mathrm{G}>\mathrm{M}$ & $\mathrm{L}>\mathrm{GL}>\mathrm{G}>\mathrm{M}$ & $\mathrm{L}>\mathrm{GL}>\mathrm{G}>\mathrm{M}$ & $\mathrm{L}>\mathrm{GL}>\mathrm{G}>\mathrm{M}$ & $\mathrm{L}>\mathrm{GL}>\mathrm{G}>\mathrm{M}$ \\
\hline & Liver (L) & $78.77 \pm 7.29$ & $67.67 \pm 14.17$ & $67.30 \pm 7.84$ & $53.65 \pm 9.63$ & $121.82 \pm 5.8$ & $78.66 \pm 10.18$ \\
\hline \multirow{3}{*}{$\mathrm{Zn}$} & Gills (GL) & $49.37 \pm 6.84$ & $53.98 \pm 7 . .5$ & $62.71 \pm 5.02$ & $52.57 \pm 7.82$ & $107.28 \pm 5.15$ & $59.08 \pm 10.50$ \\
\hline & Gonads (G) & $48.63 \pm 8.46$ & $43.93 \pm 8.24$ & $48.61 \pm 5.41$ & $50.15 \pm 8.04$ & $75.86 \pm 6.39$ & $49.66 \pm 2.89$ \\
\hline & Muscles (M) & $41.84 \pm 7.62$ & $42.87 \pm 10.49$ & $43.37 \pm 6.89$ & $46.85 \pm 7.13$ & $58.43 \pm 5.43$ & $54.69 \pm 5.76$ \\
\hline \multirow[t]{2}{*}{ Pattern } & & $\mathrm{L}>\mathrm{GL}>\mathrm{G}>\mathrm{M}$ & $\mathrm{L}>\mathrm{GL}>\mathrm{G}>\mathrm{M}$ & $\mathrm{L}>\mathrm{GL}>\mathrm{G}>\mathrm{M}$ & $\mathrm{L}>\mathrm{GL}>\mathrm{G}>\mathrm{M}$ & $\mathrm{L}>\mathrm{GL}>\mathrm{G}>\mathrm{M}$ & $\mathrm{L}>\mathrm{GL}>\mathrm{G}>\mathrm{M}$ \\
\hline & Liver (L) & $64.71 \pm 7.67$ & $68.78 \pm 12.29$ & $74.87 \pm 11.61$ & $52.86 \pm 110.79$ & $93.58 \pm 8.52$ & $87.88 \pm 6.57$ \\
\hline \multirow{3}{*}{$\mathrm{Fe}$} & Gills (GL) & $59.13 \pm 6.13$ & $57.48 \pm 11.68$ & $47.76 \pm 7.26$ & $49.66 \pm 9.82$ & $82.8 \pm 11.94$ & $63.61 \pm 16.97$ \\
\hline & Gonads (G) & $42.49 \pm 5.47$ & $43.78 \pm 13.82$ & $46.76 \pm 12.54$ & $32.38 \pm 7.01$ & $34.36 \pm 10.42$ & $57.49 \pm 8.45$ \\
\hline & Muscles (M) & $26.08 \pm 6.44$ & $34.94 \pm 7.37$ & $30.39 \pm 8.34$ & $28.56 \pm 7.63$ & $30.23 \pm 12.79$ & $29.09 \pm 8.59$ \\
\hline \multirow[t]{2}{*}{ Pattern } & & $\mathrm{L}>\mathrm{GL}>\mathrm{G}>\mathrm{M}$ & $\mathrm{L}>\mathrm{GL}>\mathrm{G}>\mathrm{M}$ & $\mathrm{L}>\mathrm{GL}>\mathrm{G}>\mathrm{M}$ & $\mathrm{L}>\mathrm{GL}>\mathrm{G}>\mathrm{M}$ & $\mathrm{L}>\mathrm{GL}>\mathrm{G}>\mathrm{M}$ & $\mathrm{L}>\mathrm{GL}>\mathrm{G}>\mathrm{M}$ \\
\hline & Liver (L) & $7.54 \pm 0.75$ & $4.05 \pm 2.53$ & $7.21 \pm 6.29$ & $7.18 \pm 5.39$ & $11.31 \pm 6.87$ & $29.77 \pm 6.26$ \\
\hline \multirow{3}{*}{$\mathrm{pb}$} & Gills (GL) & $5.42 \pm 2.80$ & $3.66 \pm 1.75$ & $6.04 \pm 2.17$ & $6.54 \pm 3.89$ & $8.01 \pm 4.05$ & $24.29 \pm 3.36$ \\
\hline & Gonads (G) & $4.21 \pm 2.29$ & $2.94 \pm 0.47$ & $5.67 \pm 1.49$ & $5.76 \pm 4.70$ & $6.9 \pm 2.45$ & $18.9 \pm 3.61$ \\
\hline & Muscles (M) & $3.99 \pm 2.64$ & $2.01 \pm 0.86$ & $4.32 \pm 1.38$ & $4.79 \pm 3.68$ & $5.36 \pm 2.66$ & $14.44 \pm 2.43$ \\
\hline \multirow[t]{2}{*}{ Pattern } & & $\mathrm{L}>\mathrm{GL}>\mathrm{G}>\mathrm{M}$ & $\mathrm{L}>\mathrm{GL}>\mathrm{G}>\mathrm{M}$ & $\mathrm{L}>\mathrm{GL}>\mathrm{G}>\mathrm{M}$ & $\mathrm{L}>\mathrm{GL}>\mathrm{G}>\mathrm{M}$ & $\mathrm{L}>\mathrm{GL}>\mathrm{G}>\mathrm{M}$ & $\mathrm{L}>\mathrm{GL}>\mathrm{G}>\mathrm{M}$ \\
\hline & Liver (L) & $6.34 \pm 1.79$ & $7.72 \pm 1.97$ & $8.89 \pm 1.7$ & $8.92 \pm 5.09$ & $13.97 \pm 2.1$ & $15.77 \pm 2.23$ \\
\hline \multirow{3}{*}{ Mn } & Gills (GL) & $4.89 \pm 2.55$ & $9.32 \pm 1.54$ & $11.27 \pm 5.54$ & $9.79 \pm 3.54$ & $17.06 \pm 3.03$ & $10.39 \pm 1.66$ \\
\hline & Gonads (G) & $4.73 \pm 1.79$ & $5.54 \pm 1.50$ & $8.46 \pm 6.29$ & $6.53 \pm 2.54$ & $16.77 \pm 4.12$ & $11.54 \pm 3.99$ \\
\hline & Muscles (M) & $3.42 \pm 1.66$ & $2.62 \pm 2.73$ & $2.72 \pm 1.67$ & $3.15 \pm 1.9$ & $3.52 \pm 0.71$ & $7.02 \pm 1.48$ \\
\hline \multirow[t]{2}{*}{ Pattern } & & $\mathrm{L}>\mathrm{GL}>\mathrm{G}>\mathrm{M}$ & $\mathrm{GL}>\mathrm{L}>\mathrm{G}>\mathrm{M}$ & $\mathrm{GL}>\mathrm{L}>\mathrm{G}>\mathrm{M}$ & $\mathrm{GL}>\mathrm{L}>\mathrm{G}>\mathrm{M}$ & $\mathrm{GL}>\mathrm{L}>\mathrm{G}>\mathrm{M}$ & $\mathrm{L}>\mathrm{GL}>\mathrm{G}>\mathrm{M}$ \\
\hline & Liver (L) & $0.005 \pm 0.01$ & $0.0009 \pm 0.001$ & $0.002 \pm 0.003$ & $0.06 \pm 0.02$ & $0.05 \pm 0.04$ & $0.04 \pm 0.02$ \\
\hline \multirow{3}{*}{$\mathrm{Hg}$} & Gills (GL) & $0.001 \pm 0.002$ & $0.004 \pm 0.01$ & $0.003 \pm 0.01$ & $0.05 \pm 0.02$ & $0.04 \pm 0.03$ & $0.03 \pm 0.02$ \\
\hline & Gonads (G) & $0.001 \pm 0.001$ & $0.0005 \pm 0.001$ & $0.002 \pm 0.004$ & $0.04 \pm 0.03$ & $0.01 \pm 0.02$ & $0.012 \pm 0.01$ \\
\hline & Muscles (M) & $0.0005 \pm 0.001$ & $0.0009 \pm 0.002$ & $0.0006 \pm 0.001$ & $0.05 \pm 0.04$ & $0.02 \pm 0.02$ & $0.013 \pm 0.01$ \\
\hline Pattern & & $\mathrm{L}>\mathrm{GL}>\mathrm{G}>\mathrm{M}$ & $\mathrm{GL}>\mathrm{M}>\mathrm{L}>\mathrm{G}$ & $\mathrm{GL}>\mathrm{G}>\mathrm{L}>\mathrm{M}$ & $\mathrm{L}>\mathrm{GL}>\mathrm{M}>\mathrm{G}$ & $\mathrm{L}>\mathrm{GL}>\mathrm{M}>\mathrm{G}$ & $\mathrm{L}>\mathrm{GL}>\mathrm{M}>\mathrm{G}$ \\
\hline
\end{tabular}


Table 3. Activities of Glucose-6-Phosphate Dehydrogenase (G6PDH) and Lactate Dehydrogenase (LDH) in liver and muscle tissues of Nile tilapia Oreochromis niloticus niloticus collected from different sites along the whole course of the river Nile, Egypt.

\begin{tabular}{ccccc}
\hline \multirow{2}{*}{ Sites } & \multicolumn{2}{c}{ G6PDH (U/g) Mean \pm SD } & \multicolumn{2}{c}{ LDH (U/g) Mean \pm SD } \\
\cline { 2 - 5 } & Liver & Muscles & Liver & Muscles \\
\hline Aswan & $57.7 \pm 5.9$ & $61.8 \pm 4.8$ & $1177.3 \pm 42.9$ & $1190.9 \pm 85.4$ \\
Kena & $42.1 \pm 3.6$ & $59.8 \pm 3.5$ & $1136.4 \pm 40.3$ & $1210.8 \pm 44.3$ \\
Assiut & $39.2 \pm 11.1^{*}$ & $50.0 \pm 5.4^{*}$ & $1191.7 \pm 34.4$ & $1232.0 \pm 40.3^{*}$ \\
Beny-Suef & $40.3 \pm 1.5^{*}$ & $42.4 \pm 2.2^{*}$ & $1172.9 \pm 40.6$ & $1227.7 \pm 17.7$ \\
Damietta & $38.2 \pm 1.6^{*}$ & $37.5 \pm 3.2^{*}$ & $1558.1 \pm 57.8^{*}$ & $1587.2 \pm 37.1^{*}$ \\
Rosetta & $28.2 \pm 5.1^{*}$ & $37.2 \pm 1.4^{*}$ & $1491.8 \pm 58.6^{*}$ & $1550.05 \pm 37.7^{*}$ \\
\hline
\end{tabular}

*Significant comparing to Aswan site at 0.05 levels.

toward downstream river Nile (Table 3). The lowest LDH activity was recorded in the liver of fish sampled from Kena and in the muscles of fish collected from Aswan (Table 3). The highest values of LDH activity was detected in the liver and muscles of Nile tilapia sampled from Damietta. The activities of G6PDH and LDH in the muscles were always higher than that in the liver of fish collected from the same site (Table 3).

\subsection{Tissues Biomarkers}

Livers of the healthy Nile tilapia displayed a normal appearance macroscopically and had a normal histological appearance as well. Hepatocytes are polygonal in shape, arranged in several cellular layers and surrounded by sinusoids (S), which could be seen to converge into the central vein $(\mathrm{V})$. Pancreatic $(\mathrm{P})$ tissue was present in association with venous vessels (Figures 2(a), (b)). Remarkable structural changes were detected in the liver of Nile tilapia collected nearly from the whole course of the Egyptian river Nile with moderate to totally damaged liver in the heavily polluted sites. The histopathological changes found in the liver of the examined fish included irregular arrangements of hepatocytes, blood congestion (bc) in blood vessel, vacuolation (vac) and necrosis (nec) (Figures 2(c), (d)). Leukocyte infiltration (inf) and hemorrhage (hem) were also detected in the hepatic tissues of some fish (Figure 3(a)). In the fishes collected from Damietta and Rosetta, patchy degeneration (pd) elements around the pancreatic cells (Figure 2(c)) and parenchyma cells (Figures 3(b), (c)) were observed with progressive increase of fibro-connective tissue (fct; Figure 3(b)). Also, dilatation of sinusoids (ds), dilatation of blood vessels (db) (Figure 3(b)) and extensive vascular congestion (Figure 3(c)) were observed. Acute and extensive vacuolation (vac) and focal areas of necrosis (nec) were observed (Figures 3(c), (d)) in the liver of fish col- lected from downstream areas.

Gill of healthy Nile tilapia displayed normal appearance (Figure 4(a)). In the core was a cartilaginous supporting rod (car) and blood vessels (bv) with traces of sinusoidal blood spaces. The primary lamella (P) was rounded at the apices while the projecting secondary lamellae (S) were clearly interspaced (Figure 4(a)).

Histological alterations in the gill of fish collected from the river Nile included fusion of adjacent secondary gill lamellae (fl) and epithelial lifting (el) (Figure 4(b)). There was also shrinkage of cartilaginous supporting mass resulting in a decrease in the size of the gills (Figures 4(b)-(d)) and curling of primary lamellae (cu) was also evident (Figure 4(c)). At Rosetta and Damietta, the

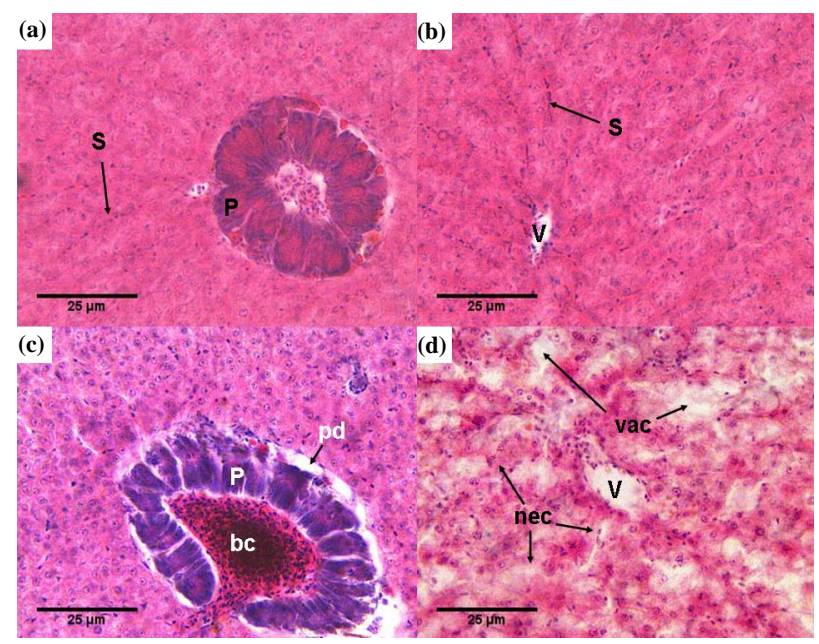

Figure 2. Photomicrograph of liver tissue showing (a), (b) Normal liver of Nile tilapia collected from Kena; (c), (d) Histopathological changes in the liver of Nile tilapia collected from Damietta and Rosetta sites. (S) sinusoid, (V) central vein, $(P)$ pancreas, (nec) necrosis, (vac) vacuolation, (pd) patchy degeneration, (bc) blood congestion. Stained with $\mathbf{H} \& \mathbf{E}$. 


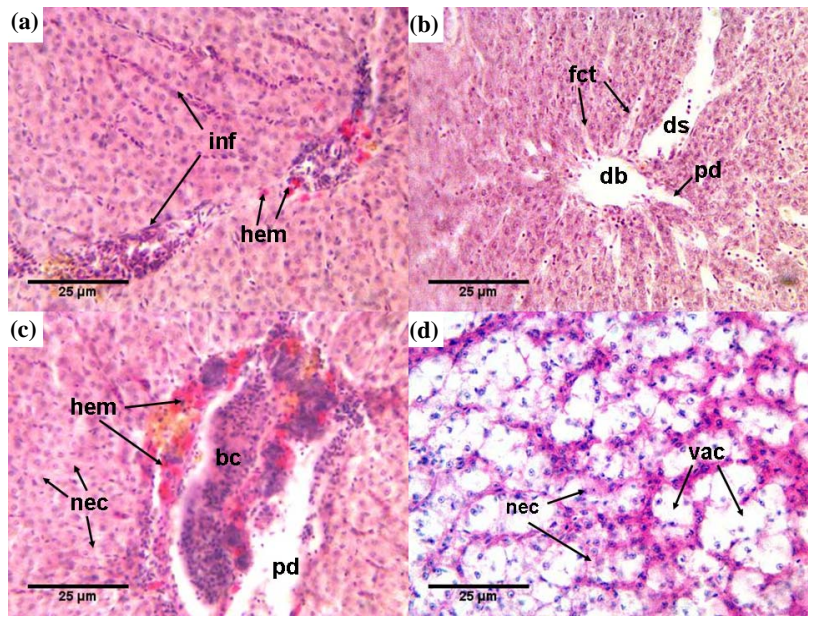

Figure 3. Photomicrograph of liver tissue showing histopathology in tissue of Nile tilapia collected from Damietta and Rosetta sites. (a) Liver tissues with leucocytes infiltration (inf) and haemorrhage (hem); (b) Showing progressive increase of fibro-connective tissue (fct), dilation of sinusoids (ds) and blood vessels (db); (c) Showing extensive haemorrhage (hem), blood congestion (bc), patchy degeneration (pd) and necrosis (nec); (d) Showing extensive vacuolation (vac) and necrosis (nec). Stained with $H \& E$.
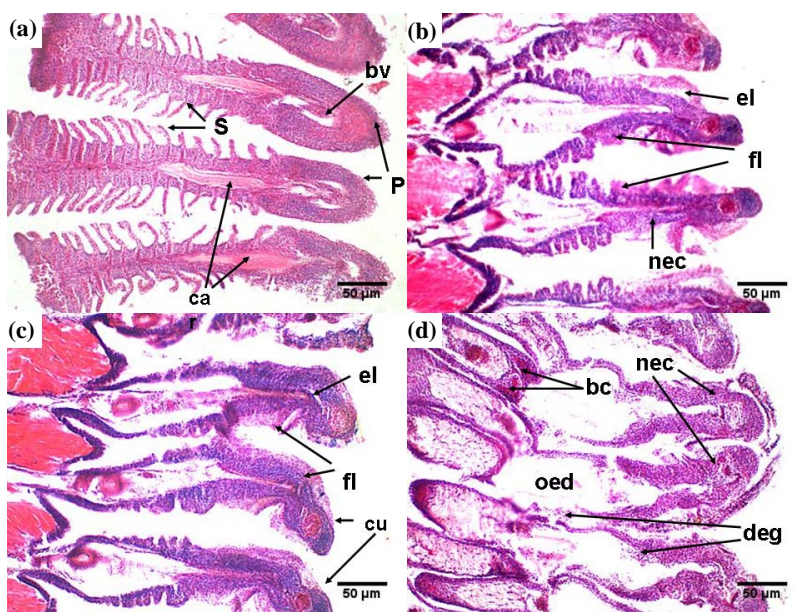

Figure 4. Photomicrograph of gills of Nile tilapia showing (a) Gill of healthy fish, collected from Aswan site, containing normal structures; (b) Histopathological changes in the gill of Nile tilapia collected from Damietta and Rosetta sites showing fusion of adjacent secondary lamellae (fl), epithelial lifting (el) and necrosis (nec); (c) Gill tissues with curling of primary lamellae (cu); (d) Gill epithelium was disrupted owing to sever degeneration (deg) and necrosis (nec) with signals onset of oedematous changes (oed). (P) Primary lamella, (S) secondary lamella, (ca) cartilage (bv) blood vessel. Stained with $H$ \& $E$.

epithelium was disrupted owing to sever degeneration (deg) and necrotic (nec) changes in gill filaments (Figure 4(d)). The increase in intracellular vacuolation (Figure 4(d)) signals onset of oedematous changes (oed). Fre- quently, alterations such as dilation and congestion in blood vessel (bc) were detected (Figure 4(d)). The gills show further shrinkage making the cartilaginous core absolutely obscured.

\section{Discussion}

While most of the Nile's water quality is within acceptable levels, there are several hot spots mostly found in downstream areas of the river Nile. Most of the detected physical and chemical parameters were significantly higher in the water samples collected from downstream areas (Rosetta and Damietta sites) compared to sites located upstream. Detailed investigation about the level of physical and chemical parameters in water and sediment of the selected sites have been presented previously [1]. From that study we concluded that mean values of conductivity, chemical oxygen demand (COD), total organic carbon (TOC), ammonia $\left(\mathrm{NH}_{3}\right)$, nitrate $\left(\mathrm{NO}_{3}\right)$, total solid (TS), sulphate $\left(\mathrm{SO}_{4}\right)$, chloride $(\mathrm{Cl})$, orthophosphate and phenolics were recorded to be higher in the water of Damietta and Rosetta sites compared to the other sites. Also heavy metals levels increased in the water and sediment significantly from upstream to downstream areas. Such increase proves the presence of large quantities of organic and inorganic pollutants in the sites located downstream river Nile [1]. Physicochemical analysis gave useful information on the levels of contamination along the whole course of the Egyptian river Nile but, generally, did not give information on the effects of the contaminants on biological systems. So, it was essential to use biomarker responses in fishes. Here I present data on bioaccumulation, biochemical and tissues biomarkers in Nile tilapia (Oreochromis niloticus niloticus) as early warning indicators of river Nile pollution.

Bioaccumulation is the ability of fish to concentrate an element from water to a level higher than that of its environment. Therefore, bioaccumulation of metals in fish can be considered as an index of metal pollution in the aquatic bodies [30,31]. Fish surviving at highly polluted areas accumulate higher levels of heavy metals than those surviving at less polluted areas [32]. In the present work, Nile tilapia sampled from downstream river Nile accumulated higher levels of all the detected heavy metals than those collected from upstream sites. Mean levels of the selected heavy metals in the tissues of Nile tilapia followed the same pattern as in water, in being higher at Damietta and Rosetta. This indicated a close correlation between the concentrations of metals in water and in fish tissues. Heavy metal residues in the tissues of Nile tilapia exhibited different patterns of accumulation and distribution among the selected tissues and localities. Effects of high concentrations of heavy metals on fish are not well 
established; however, there is evidence that high concentrations in fish can experience toxicity [33]. Some heavy metals as copper can combine with other contaminants to produce an additive toxic effect on fish [34]. Chromium bioaccumulation in fish has been reported to cause impaired respiratory and osmoregulatory functions through structural damage to gill epithelium [9]. Cadmium and lead are highly toxic non-essential heavy metals and they do not have a role in biological processes in living organisms [35]. Thus even in low concentration, $\mathrm{Cd}$ and $\mathrm{Pb}$ could be harmful to fishes. Lead was found to cause pathological changes in tissue and organs. Manganese functions as an essential constituent for bone structure, reproduction and normal functioning of the enzymes system [35]. It is toxic only when present in higher amount, but at low level is considered as micronutrient [35].

According to the current results, the highest concentrations of all the detected heavy metals (excluded Mn) were recorded in the liver tissues followed by gills. The distributions of all these heavy metals were in the order of liver $>$ gill $>$ gonad $>$ muscle. The high concentration of these metals in the liver is related to the fact that the liver plays an important role in accumulation. High accumulation of metals in liver may be due to their strong binding with cystine residues of metallothionein (MT), which serves as a detoxification mechanism [34]. MT has high affinities for heavy metals and in doing so, concentrate and regulate these metals in the liver [36]. The lower concentration of nearly all the detected metals in gills (compared to liver) was possibly due to lower binding affinity of metals on the gill surface. Such low accumulation may also be due to development of some defensive mechanism such as excessive mucous secretion and clogging of gills. Gonad and muscle were found to accumulate small amounts of all the heavy metals and might have received them through circulation. It is suggested that the low accumulation of metals in gonad and muscle may be due to lack of binding affinity of these metals with the proteins of gonad and muscle. This is particularly important because muscles contribute the greatest mass of the flesh that is consumed as food. Heavy metal concentrations reported in the present study is consistent and within the range reported in a previous study that evaluated metal contamination of African catfish sampled from the rive Nile [1].

Biochemical biomarkers are among the first measurable responses to the presence of chemical pollutants and thus are early, sensitive indicators of possible damage at higher levels of organization [37]. The alteration in enzyme activity has been advocated to provide an early warning of potentially damaging changes in stressed fish. Especially LDH and G6PDH have been employed for diagnosing liver and muscle damages caused by pollutants in fish [38] and could be useful biomarkers of water pollution. Remarkable alterations in the activity of both enzymes were detected in the present study. These alterations go in parallel with the elevation in the levels of water chemical parameters detected in the downstream river Nile as a result of pollution stress in these areas. The activity of G6PDH was significantly decreased from upstream to downstream river Nile recording the lowest values at Rosetta and/or Damietta water. Such reduction in G6PDH activity in the liver and muscles of Nile tilapia was previously recorded in some fishes exposed to toxicants [22,39]. A reduction in G6PDH activity in the liver was also observed in bullhead (Cottus gobio) exposed to paper mill effluents [40]. Thus the observed decrease in activity of G6PDH in the present work may reflect metabolic imbalance after pollution stress in direct relation to the limited availability of NADPH [22]. This probably reflects an adaptation to oxidative conditions to which fish have been exposed. GSH is used by antioxidant defense mechanisms and its production requires NADPH to be synthesized in the pentose phosphate metabolic pathway in which G6PDH participate. For this reason, G6PDH is considered as antioxidant enzyme [41]. The decreased activities of G6PDH with higher concentrations of metals in downstream river Nile are most likely related to the displacement of magnesium cofactor by cadmium, copper or other metals such that the enzyme lost sensitivity to magnesium activation [16].

LDH commonly reflects the metabolic capacity of tissues after long-term exposure to contaminated water bodies $[22,42]$. The activity of $\mathrm{LDH}$, which is a cytoplasmic enzyme, showed a marked elevation in the tissues of Nile tilapia collected from downstream river Nile compared to other sites. LDH activity is generally associated with cellular metabolic activity and is a pivotal enzyme between the glycolytic pathway and the tricarboxylic acid cycle [43]. Thus, elevation of LDH may suggest a bias towards the anaerobic glycolytic pathway. By other meaning, changes in the lactate dehydrogenase activity may indicate the facility with which the Nile tilapia can shift to anaerobic metabolism under stressed conditions. Anaerobic capacity was most impacted in the tissues of fish collected from heavily polluted sites with the LDH activity in the tissues of fish from downstream river Nile higher than that of fish sampled from upstream river Nile. Liver and muscles of Nile tilapia seem to be able to react strongly to the presence of higher chemical pollution by increasing anaerobic capacity, possibly facilitating elimination of offending chemicals [44]. LDH activity in muscle was always higher than that in liver. This biochemical response also complies with low partial pressure and oxygen concentrations in the muscle, 
prompting increased anaerobic capacity.

Histopathological biomarkers can be used as indicators for the effects of various anthropogenic pollutants on organisms and are a reflection of the overall health of the entire population in the ecosystem [45]. The severity of damage depends on the toxic potentiality of a particular toxicant accumulated in the tissue. Therefore, exposure to polluted water may adversely affect various organs in fish which ultimately could lead to overall toxic impact on organs like gill and liver [46]. Different kind of toxicity effects were noticed in various fish exposed to different pollutants $[18,22,47]$. Liver as the main organ of metabolism comes into contact with xenobiotics absorbed from the aquatic environment and liver lesions are often associated with exposure to aquatic pollutants [48]. One of the most important functions of liver is to clean pollutants from the blood coming from the intestine, so it is considered as indicator of aquatic environmental pollution. The monitoring of histological changes in fish liver is a highly sensitive and accurate way to assess the effects of xenobiotic compounds in field [18]. The fish that was sampled from upstream river Nile showed healthy liver structure. In the present study irregular arrangements of hepatocytes, leukocyte infiltration, necrosis and vacuolation of hepatocytes was observed in the livers of Nile tilapia collected from the whole course of the river Nile even though their livers were normal in appearance macroscopically. The most prominent histological alterations observed in the fish that showed abnormal livers macroscopically were dilation of blood vessels and sinusoids, severe congestion in sinusoids and blood vessels, increased vacuolation of hepatocytes and focal areas of necrosis. Vacuolation of hepatocyte is a nonspecific response of fish due to toxic conditions (Roberts 1978). The vacuolization of hepatocytes might indicate an imbalance between the rate of synthesis of substances in the parenchyma cells and the rate of their release into the circulation [49]. Severe congestion in sinusoids and small blood vessels makes the blood flow from the hepatic portal vein and hepatic artery into the central vein rather difficult. This may be responsible for the cellular degeneration and necrosis in the livers of some Nile tilapia collected from downstream river Nile. Observed liver abnormalities reflect the biological impacts of complex mixture of pollutants present in this downstream areas of the river Nile.

Gills are the first target of waterborne pollutants due to the constant contact with water, as well as the main place for some heavy metals uptake [50]. It is well known that changes in fish gill are among the most commonly recognized responses to aquatic pollutants [50]. Histological study of the gills showed a typical structural organization of the lamella in the fishes collected from upstream river
Nile. However, fish sampled from heavily polluted sites (downstream areas) showed several histological alterations, namely fusion of gill lamellae, epithelial lifting, necrosis, curling of primary lamellae, shrinkage of cartilaginous supporting mass, sever degeneration in gill filaments and dilation and congestion in blood vessel. The cellular damages observed in the gills in term of epithelial lifting and necrosis can adversely affect the gas exchange and ionic regulation. As a consequence of the increased distance between water and blood due to epithelial lifting, the oxygen uptake is impaired. However, fishes have the capacity to increase their ventilation rate, to compensate low oxygen uptake. Fusion of some secondary lamellae is an example of defense mechanisms that reduce the branchial superficial area in contact with the external environment [18]. The observed edematous changes in gill filaments is probably due to increased capillary permeability $[22,47]$. Edema could serve as a mechanism of defense, because separation of the epithelium of the lamellae increases the distance across which waterborne pollutants must diffuse to reach the bloodstream [18]. These mechanisms also increase the diffusion barrier to the pollutants [51]. Similar lesions have been previously reported by some authors in some fish species exposed to different kind of pollution [22,52-54]. This means, such alterations are non-specific and may be induced by different types of contaminants.

\section{Conclusion}

It is evident from this study that, liver was the site of maximum accumulation for the elements while muscle was the overall site of least metal accumulation. Altered activities of G6PDH and LDH can provide a useful biomarker for environmental managers in investigating the exposure of fish to contaminated waters. Histopathological lesions provide a reliable, easily quantifiable index of low-level toxic stress to a broad range of environmental pollutants. These results provide evidence that bioaccumulation, biochemical and tissue biomakers can be sensitive indicators of exposure to mixed organic pollutants in surface waters.

\section{Acknowledgements}

This work was supported by Science and Technology development fund, Egypt (Project ID 448). Most of this study were conducted during 2010-2012 in the framework of my Alexander von Humboldt foundation postdoctoral fellowship (3.4-AGY/1134716 STP), hosted by Leibniz-Institute of Freshwater Ecology and Inland Fisheries (IGB), Berlin, Germany. My special thanks go to Prof. Dr. Werner Kloas who offered me a warm welcome and gave me the opportunity to use the research facilities 
in his department. I would like to thank Mr. A. Gad El-Rab, A. Moustafa, M. Nassar, R. Said, Department of Zoology (Al-Azhar University, Egypt) for their support during sampling. I gratefully acknowledge Dr. Alaa ElDin Sayed, Department of zoology (Assiut University, Egypt) for his help during enzyme analysis.

\section{REFERENCES}

[1] A. G. M. Osman and W. Kloas, "Water Quality and Heavy Metal Monitoring in Water, Sediments and Tissues of the African Catfish Clarias gariepinus (Burchell, 1822) from the River Nile, Egypt," Journal of Environmental Protection, Vol. 1, 2010, pp. 389-400. doi:10.4236/jep.2010.14045

[2] A. G. M. Osman, A. M. Abd El Reheem, M. A. Moustafa, U. M. Mahmoud, K. Y. Abuel-Fadl and W. Kloas, "In Situ Evaluation of the Genotoxic Potential of the River Nile: I. Micronucleus and Nuclear Lesion Tests of Erythrocytes of Oreochromis niloticus niloticus (Linnaeus, 1758) and Clarias gariepinus (Burchell, 1822)," Toxicological and Environmental Chemistry, Vol. 93, No. 5, 2011, pp. 1002-1017. doi:10.1080/02772248.2011.564496

[3] R. Tejeda-Vera, E. Lopez-Lopez and J. E. Sedeno-Diaz, "Biomarkers and Bioindicators of the Health Condition of Ameca splendens and Goodea atripinnis (Pisces: Goodeaidae) in the Ameca River, Mexico," Environment International, Vol. 33, No. 4, 2007, pp. 521-531. doi:10.1016/j.envint.2006.11.018

[4] H. I. Falfushynska and O. B. Stolyar, "Responses of Biochemical Markers in Carp Cyprinus carpio from Two Field Sites in Western Ukraine," Ecotoxicology and Environmental Safety, Vol. 72, No. 3, 2009, pp. 729-736. doi:10.1016/j.ecoenv.2008.04.006

[5] G. Ambedkar and M. Muniyan, "Bioaccumulation of Some Heavy Metals in the Selected Five Freshwater Fish from Kollidam River, Tamilnadu, India," Advances in Applied Science Research, Vol. 2, No. 5, 2011, pp. 221225.

[6] A. A. Otitoloju, "Evaluation of the Joint-Action Toxicity of Binary Mixtures of Heavy Metals against the Mangrove Periwinkle Tympanotonus fuscatus var radula (L.)," Ecotoxicology and Environmental Safety, Vol. 53, No. 3, 2002, pp. 404-415. doi:10.1016/S0147-6513(02)00032-5

[7] N. Barak and C. Mason, "Mercury, Cadmium and Lead in Eels and Roach: The Effects of Size, Season and Locality on Metal Concentrations in Flesh and Liver," Science of the Total Environment, Vol. 92, 1990, pp. 249-256. doi:10.1016/0048-9697(90)90334-Q

[8] I. Haluzova, H. Modra, J. Blahova, M. Havelkova, Z. Siroka and Z. Svobodova, "Biochemical Markers of Contamination in Fish Toxicity Tests," Interdisciplinary Toxicology, Vol. 4, No. 2, 2011, pp. 85-89.

[9] A. G. Heath, "Water Pollution and Fish Physiology," Lewis Publs., Boca Raton, 1996.
[10] P. P. Pandolfi, F. Sonati, R. Rivi, P. Mason, F. Grosveld and L. Luzzatto, "Targeted Disruption of the Housekeeping Gene Encoding Glucose 6-Phosphate Dehydrogenase (G6PD): G6PD Is Dispensable for Pentose Synthesis But Essential for Defense against Oxidative Stress," The EMBO Journal, Vol. 14, No. 21, 1995, pp. 5209-5215.

[11] P. C. Das, S. Ayyappan, B. K. Das and J. K. Jena, "Nitrite Toxicity in Indian Major Carps: Sublethal Effect on Selected Enzymes in Fingerlings of Catla catla, Labeo rohita and Cirrhinus mrigala," Comparative Biochemistry and Physiology. Toxicology \& Pharmacology: CBP, Vol. 138, No. 1, 2004, pp. 3-10.

[12] P. C. Das, S. Ayyappan, J. K. Jena and B. K. Das, “Acute Toxicity of Ammonia and Its Sub-Lethal Effects on Selected Haematological and Enzymatic Parameters of Mrigal, Cirrhinus mrigala (Hamilton)," Aquaculture Research, Vol. 35, No. 2, 2004, pp. 134-143. doi:10.1111/j.1365-2109.2004.00994.x

[13] S. M. Long, K. J. Ryder and D. A. Holdway, "The Use of Respiratory Enzymes as Biomarkers of Petroleum Hydrocarbon Exposure in Mytilus edulis Planulatus," Ecotoxicology and Environmental Safety, Vol. 55, No. 3, 2003, pp. 261-270. doi:10.1016/S0147-6513(02)00137-9

[14] D. Bernet, H. Schmidt, W. Meier, P. Burkhardt-Holm and T. Wahli, "Histopathology in Fish: Proposal for a Protocol to Assess Aquatic Pollution," Journal of Fish Diseases, Vol. 22, No. 1, 1999, pp. 25-34. doi:10.1046/j.1365-2761.1999.00134.x

[15] S. J. Teh, S. M. Adams and D. E. Hintonm, "Histopathologic Biomarkers in Feral Freshwater Fish Populations Exposed to Different Types of Contaminant Stress," Aquatic Toxicology, Vol. 37, 1997, pp. 51-70. doi:10.1016/S0166-445X(96)00808-9

[16] S. J. The, S. L. Clark, C. L. Brown, S. N. Luoma and D. E. Hinton, "Enzymatic and Histopathologic Biomarkers as Indicators of Contaminant Exposure and Effect in Asian Clam (Potamocorbula amurensis)," Biomarkers, Vol. 4, No. 6, 1999, pp. 497-509. doi:10.1080/135475099230660

[17] H. Moeller, "A Critical Review on the Role of Pollution as a Cause of Fish Diseases," In: A. E. Ellis, Ed., Fish and Shellfish Pathology, European Association of Fish Pathology, Academic Press, London, 1985, pp. 169-182.

[18] A. Figueiredo-Fernandes, J. V. Ferreira-Cardoso, S. Garcia-Santos, S. M. Monteiro, J. Carrola, P. Matos and A. Fontainhas-Fernandes, "Histopathological changes in Liver and Gill Epithelium of Nile Tilapia, Oreochromis niloticus, Exposed to Waterborne Copper," Pesquisa Veterinaria Brasileira, Vol. 27, No. 3, 2007, pp. 103-109. doi:10.1590/S0100-736X2007000300004

[19] A. Figueiredo-Fernandes, A. Fontainhas-Fernandes, R. Monteiro, M. A. Reis-Henriques and E. Rocha, "Effects of the Fungicide Mancozeb on Liver Structure of Nile Tilapia, Oreochromis niloticus: Assessment and Quantification of Induced Cytological Changes Using Qualitative Histopathology and the Stereological Point-Sampled Intercept Method," Bulletin of environmental contamination and toxicology, Vol. 76, No. 2, 2006, pp. 249-255. doi:10.1007/s00128-006-0914-1 
[20] A. G. M. Osman, E. Ali, M. Hashem, M. Mostafa and I. Mekkawy, "Genotoxicity of Two Pathogenic Strains of Zoosporic Fungi (Achlya klebsiana and Aphanomyces laevis) on Erythrocytes of Nile Tilapia Oreochromis niloticus niloticus," Ecotoxicology and environmental safety, Vol. 73, No. 1, 2010, pp. 24-31.

doi:10.1016/j.ecoenv.2009.08.021

[21] B. K. M. Gadagbui, M. Addy and A. Goksoyr, "Species Characteristics of Hepatic Biotransformation Enzymes in two Tropical Freshwater Teleosts, Tilapia (Oreochromis niloticus) and Mudfish (Clarias anguillaris)," Comparative Biochemistry and Physiology C-Pharmacology Toxicology \& Endocrinology, Vol. 114, No. 3, 1996, pp. 201211.

[22] A. G. M. Osman, A. M. Abd El Reheem, K. Y. AbuelFadl and A. G. GadEl-Rab, "Enzymatic and Histopathologic Biomarkers as Indicators of Aquatic Pollution in Fishes," Natural Science, Vol. 2, No. 11, 2010, pp. 13021311. doi:10.4236/ns.2010.211158

[23] A. G. Osman, K. Y. Abuel-Fadl and W. Kloas, "In Situ Evaluation of the Genotoxic Potential of the River Nile: II. Detection of DNA Strand-Breakage and Apoptosis in Oreochromis niloticus niloticus (Linnaeus, 1758) and Clarias gariepinus (Burchell, 1822)," Mutation Research, Vol. 747, 2012, pp. 14-21. doi:10.1016/i.mrgentox.2012.02.013

[24] APHA, "Standard Methods for the Examination of Water \& Wastewater," Amer Public Health Assn, 2005.

[25] I. Hardewig, H. O. Pörtner and P. van Dijk, "How Does the Cold Stenothermal Gadoid Lota lota Survive High Water Temperatures during Summer?" Journal of Comparative Physiology. B, Biochemical, Systemic and Environmental Physiology, Vol. 174, No. 2, 2004, pp. 149156. doi:10.1007/s00360-003-0399-8

[26] A. G. M. Osman, I. A. A. Mekkawy, J. Verreth and F. Kirschbaum, "Effects of Lead Nitrate on the Activity of Metabolic Enzymes during Early Developmental Stages of the African Catfish Clarias gariepinus (Burchell, 1822)," Fish Physiology and Biochemistry, Vol. 33, 2007, pp. 1-13. doi:10.1007/s10695-006-9111-8

[27] J. D. Bancroft and A. Stevens, "Theory and Practice of Histological Techniques," 4th Edition, Churchill Livingstone, New York, 1996.

[28] SPSS, "SPSS-Inc. for Windows Release," Vol. 10, Chicago, 1998.

[29] Statistica, "StatSoft-Inc. for Windows Release, USA," 2007.

[30] M. Javed, "Heavy Metal Contamination of Freshwater Fish and Bed Sediments in the River Ravi Stretch and related Tributaries," Pakistan Journal of Biological Sciences, Vol. 8, No. 10, 2005, pp. 1337-1341. doi:10.3923/pjbs.2005.1337.1341

[31] H. Karadede-Akin and E. Unlü, "Heavy Metal Concentrations in Water, Sediment, Fish and Some Benthic Organisms from Tigris River, Turkey," Environmental Monitoring and Assessment, Vol. 131, No. 1-3, 2007, pp. 323-337. doi:10.1007/s10661-006-9478-0
[32] M. Bahnasawy, A. A. Khidr and N. Dheina, "Seasonal Variations of Heavy Metals Concentrations in Mullet, Mugil Cephalus and Liza Ramada (Mugilidae) from Lake Manzala, Egypt," Applied Sciences Research, Vol. 5, No. 7, 2009, pp. 845-852.

[33] L. A. Woodward, M. Mulvey and M. C. Newman, "Mercury Contamination and Population-Level Responses in Chironomids: Can Allozyme Polymorphism Indicate Exposure?" Environmental Toxicology and Chemistry, Vol. 15, No. 8, 1996, pp. 1309-1316. doi:10.1002/etc. 5620150808

[34] A. M. Yacoub, "Study on Some Heavy Metals Accumulated in Some Organs of Three River Nile Fishes from Cairo and Kalubia Governorates," African Journal of Biological Science, Vol. 3, 2007, pp. 9-21.

[35] A. El-Naggar, S. Mahmoud and S. Tayel, "Bioaccumulation of Some Heavy Metals and Histopathological Alterations in Liver of Oreochromis niloticus in Relation to Water Quality at Different Localities along the River Nile, Egypt," World Journal of Fish and Marine Sciences, Vol. 1, No. 2, 2009, pp. 105-114.

[36] J. A. McCarter and M. Roch, "Hepatic Metallothionein and Resistance to Copper in Juvenile Coho Salmon," Comparative Biochemistry and Physiology. C, Comparative Pharmacology and Toxicology, Vol. 74, No. 1, 1983, pp. 133-137. doi:10.1016/0742-8413(83)90164-0

[37] L. Vigano, A. Arillo, F. Melodia, P. Arlati and C. Monti, "Biomarker Responses in Cyprinids of the Middle Stretch of the River Po, Italy," Environmental Toxicology and Chemistry, Vol. 17, No. 3, 1998, pp. 404-411. doi:10.1002/etc.5620170309

[38] V. Lenartova, K. Holovska, J. R. Pedrajas, E. MartinezLara, J. Peinado, J. LopezBarea, I. Rosival and P. Kosuth, "Antioxidant and Detoxifying Fish Enzymes as Biomarkers of River Pollution," Biomarkers, Vol. 2, No. 4, 1997, pp. 247-252. doi:10.1080/135475097231625

[39] B. Korsgaard, "Metabolic Changes Associated with 17alpha-thinylestradiol Exposure in the Pregnant Teleost Zoarces Viviparous," Electric Journal of Ichthyology, Vol. 1, 2005, pp. 10-20.

[40] F. Bucher, R. Hofer, G. Krumschnabel and C. Doblander, "Doblander in the Prooxidant-Antioxidant Balances in the Liver of Bullhead (Cottus gobio) Exposed to Treated Paper Mill Effluents," Chemosphere, Vol. 27, 1993, pp. 1329-1338. doi:10.1016/0045-6535(93)90227-V

[41] R. Reiter, L. Tang, J. J. Garcia and A. MunozHoyos, "Pharmacological Actions of Melatonin in Oxygen Radical Pathophysiology," Life Sciences, Vol. 60, No. 25, 1997, pp. 2255-2271. doi:10.1016/S0024-3205(97)00030-1

[42] M. M. Gagnon and D. A. Holdway, "Metabolic Enzyme Activities in Fish Gills as Biomarkers of Exposure to Petroleum Hydrocarbons," Ecotoxicology and Environmental Safety, Vol. 44, No. 1, 1999, pp. 92-99. doi:10.1006/eesa.1999.1804

[43] A. R. Chourpagar and G. K. Kulkarni, "Toxic Effect of Copper Sulphate on Lactate Dehydrogenase Activity in a 
Freshwater Crab, Barytelphusa cunicularis (Westwood)," World Journal of Zoology, Vol. 4, No. 3, 2009, pp. 180183.

[44] A. Cohen, M. M. Gagnon and D. Nugegoda, "Alterations of Metabolic Enzymes in Australian Bass, Macquaria Novemaculeata, after Exposure to Petroleum Hydrocarbons," Archives of Environmental Contamination and Toxicology, Vol. 49, No. 2, 2005, pp. 200-205. doi:10.1007/s00244-004-0174-1

[45] Z. Khoshnood, S. Khodabandeh, S. Mosafer and R. Khoshnood, "Effects of Cortisol on Gill Chloride Cells in Persian Sturgeon, Acipenser persicus, Fry," Yakhteh, Vol. 11, No. 4, 2010, pp. 424-431.

[46] A. Parvathi, P. Sivakumari and C. Sarasu, "Effect of Chromium on Histological Alteration of Gill, Liver and Kindey of Freshwater Teleost, Cyprinus caprio (L.)," Journal of Fisheries International, Vol. 6, No. 1, 2011, pp. 1-5. doi:10.3923/ifish.2011.1.5

[47] E. Olojo, K. Olurin, G. Mbaka and A. Oluwemimo, "Histopathology of the Gill and Liver Tissues of the African Catfish Clarias gariepinus Exposed to Lead," African Journal of Biotechnology, Vol. 4, No. 1, 2005, pp. 117-122.

[48] C. Fernandes, A. Fontainhas-Fernandes, E. Rocha and M. A. Salgado, "Monitoring Pollution in Esmoriz-Paramos Lagoon, Portugal: Liver Histological and Biochemical Effects in Liza saliens," Environmental Monitoring and Assessment, Vol. 145, No. 1-3, 2008, pp. 315-322. doi:10.1007/s10661-007-0041-4
[49] W. H. Gingerich, "Hepatic Toxicology of Fishes," In: L. J. Weber, Ed., Aquatic Toxicology, Raven Press, New York, 1982, pp. 55-105.

[50] P. Laurent and S. F. Perry, "Environmental-Effects on Fish Gill Morphology," Physiological Zoology, Vol. 64, No. 1, 1991, pp. 4-25.

[51] D. van Heerden, A. Vosloo and M. Nikinmaa, "Effects of Short-Term Copper Exposure on Gill Structure, Metallothionein and Hypoxia-Inducible Factor-1alpha (HIF-1 alpha) Levels in Rainbow Trout (Oncorhynchus mykiss)," Aquatic Toxicology, Vol. 69, No. 3, 2004, pp. 271-280. doi:10.1016/j.aquatox.2004.06.002

[52] E. Fanta, F. S. A. Rios, S. Romão, A. C. C. Vianna and S. Freiberger, "Histopathology of the Fish Corydoras paleatus Contaminated with Sublethal Levels of Organophosphorus in Water and Food," Ecotoxicology and environmental safety, Vol. 54, No. 2, 2003, pp. 119-130. doi:10.1016/S0147-6513(02)00044-1

[53] C. B. R. Martinez, M. Y. Nagae, C. T. B. V. Zaia and D. A. M. Zaia, "Acute Morphological and Physiological Effects of Lead in the Neotropical Fish Prochilodus lineatus," Brazilian Journal of Biology = Revista brasleira de biologia, Vol. 64, No. 4, 2004, pp. 797-807.

[54] R. Triebskorn, I. Telcean, H. Casper, A. Farkas, C. Sandu, G. Stan, O. Colărescu, T. Dori and H.-R. Köhler, "Monitoring Pollution in River Mureş, Romania, Part II: Metal Accumulation and Histopathology in Fish," Environmental Monitoring and Assessment, Vol. 141, No. 1-3, 2008, pp. 177-188. doi:10.1007/s10661-007-9886-9 